\title{
PENGARUH KEMAMPUAN KOMUNIKASI MATEMATIS TERHADAP KEMAMPUAN PEMECAHAN MASALAH PADA SISWA SMP KELAS 9
}

\author{
Putri Ramadhani Fitri ${ }^{1}$, Heni Pujiastuti ${ }^{1}$ \\ ${ }^{1}$ Universitas Sultan Ageng Tirtayasa, Jalan Raya Jkt Km 4 Jl. Pakupatan,Banten 42122, Indonesia \\ Email: putriramadhan56@gmail.com \\ Email: henipujiastuti@untirta.ac.id
}

\begin{abstract}
Abstrak
Penelitian kuantitatif ini dilakukan untuk melihat adanya pengaruh komunikasi matematis dan kemampuan pemecahan masalah matematis pada siswa sekolah menengah pertama kelas 9. Penelitian ini merupakan penelitian deskriptif kuantitatif dengan metode korelasi yang diambil sampel yaitu siswa kelas XI SMP Negeri 11 Cilegon berjumlah 27 siswa. Pengambilan sampel menggunakan purposive random sampling. Pengambilan data pada kemampuan komunikasi matematis dikumpulkan dengan angket dan kemampuan pemecahan masalah menggunakan tes essay. Setelah didapatkan datanya maka dianalisis dengan uji regresi yang diuji dahulu dengan uji prasyarat (uji normalitas). Hasil analisis data menunjukan tidak ada pengaruh signifikan antara kemampuan komunikasi matematis terhadap kemampuan pemecahan masalah. Dan tingkat pengaruh kemampuan komunikasi terhadap kemampuan pemecahan masalah adalah 5.9\%
\end{abstract}

\section{Kata kunci: Kemampuan Komunikasi Matematis, Kemampuan Pemecahan Masalah}

\begin{abstract}
This quantitative research was conducted to see the influence of mathematical communication and mathematical problem solving abilities in grade 9 junior high school students. This research was a quantitative descriptive study, with correlation method, sampel are taken from class XI student of SMP Negeri 11 Cilegon with 27 students. Sampling using with purposive random sampling. Retrieval of data on mathematical communication skills collected by questionnaires and problem solving abilities using essay tests. After obtaining the data, it is analyzed with a regression test that is tested first with a prerequisite test (normality test). The results of data analysis showed that there was no significant effect between mathematical communication skills and problem solving abilities. And the level of influence of communication skills on problem solving skills is 5.9\%
\end{abstract}

Keywords: Mathematical Communication Skills, Problem Solving Abilities

\section{PENDAHULUAN}

Standar pendidikan dasar dan menengah mempunyai tujuan yaitu pemecahan masalah yang berupa kemampuan pemahaman masalah, perancangan model matematika, penjelasan model dan penafsiran solusi yang didapatkan. Selain itu, siswa harus memiliki kemampuan pengkomunikasian gagasan dengan berbagai cara. Dengan melihat tujuan tersebut maka komunikasi matematis dan kemampuan yang penting ialah kemampuan pemecahan masalah. Terlebih pada era ini dimana persaingan dalam dunia kerja membuat perserta didik ddipersiapkan untuk menjadi manusia yang unggul dan dapat bersaing dalam kehidupan saat ini.

Komunikasi matematis sendiri adalah sarana dalam penyampaian informasi sehingga siswa mempunyai kemampuan lain yang dapat membantu dalam proses pembelajaran. Dalam penyampaian 
informasi yang menjadi sumbernya adalah seorang guru yang disampaikan berupa simbol baik lisan, tulisan maupun non verbal. Hal ini membuat siswa memberi respon berupa tanggapan terhadap proses pemberian informasi tersebut.

Proses pembelajaran matematika yang mengutamakan kemampuan komunikasi matematis membuat kemampuan lainnya seperti kemampuan pemecahanan masalah juga meningkat. Kemampuan komunikasi membantu informasi dan penyampaian untuk mendapatkan kemampuan pemecahan masalah yang baik, bisa berupa pertanyaan bila informasi kurang jelas ataupun penyampaian kembali informasi yang telah disampaikan.

Halmos menyatakan dalam pembelajaran pemecahan masalah adalah jantung matematika. Sehingga pada matematika sering ditemukan berupa masalah dalam implementasi kehidupan yang melibatkan pemecahan masalah dan hitungan (Prabawanto, 2013).

Pemecahan masalah dalam matematika merupakan hasil dalam prestasi pembelajaran yang akan diterima oleh peserta didik. Walaupun sudah banyak guru yang melihat tidak hanya dari kemampuan pemecahan masalah saja dalam pemberian hasil prestasi, tetapi dalam proses pembelajaran sendiri yang selalu dilihat adalah pemecahan masalah tersebut.

Dua kemampuan tersebut perlu dibangun mulai dari sekolah dasar. Terlebih dalam pembelajaran siswa sekolah menengah pertama, dimana mereka mulai menghadapi pembelajaran yang bersifat abstrak dan tingkat kesulitan yang mulai tinggi.

Kelas 9 sekolah menengah pertama mempunyai beban yang lebih berat dalam pembelajaran kelas lainnya, dikarenakan adanya ujian nasional dan ujian sekolah. Dalam materi pembelajaran kelas 9 mencangkup semua tingkatan kelas yaitu kelas 7,8 dan kelas 9 itu sendiri membuat beban kelas 9 tiga kali lipat dari kelas lainnya. Namun dalam proses komunikasi matematis kelas 9 merupakan kelas yang lebih berani dan aktif dalam komunikasi matematis karena telah menjalani 2 tahun pembelajaran sehingga mengenal baik teman kelasnya ataupun guru.

Berdasarkan latarbelakang tersebut menduga adanya hubungan kemampuan komunikasi matematis terhadap kemampuan pemecahan masalah. Dugaan itu membuat peneliti ingin mengetahui pengaruh kemampuan komunikasi matematis terhadap kemampuan pemecahan masalah matematis pada SMP kelas 9.

\section{METODE PENELITIAN}

\section{Rancangan Penelitian ini}

Pada penelitian tersebut menggunakan metode keterkaitan atau korelasi. Tujuan metode mengukur hubungan antara dua kemampuan tersebut. Subjek pada penelitian adalah SMPN 11 Cilegon. Pemilihan jenjang dipilih dengan memprioritaskan kemampuan komunikasi matematis yang 
paling baik dan aktif dibandingkan jenjang lainnya. Sebab Hal tersebut kelas IX dipilih menjadi sampel dengan memilih salah satu kelas.

Data yang didapatkan pada komunikasi matematis dengan menggunakan angket dan pada kemampuan pemecahan masalah menggunakan tes tertulis dengan banyak 5 soal. Angket untuk komunikasi matematis berjumlah 30 pernyataan yang berupa pernyataan positif dengan penilaian skala 4 yaitu Sangat setuju, Setuju, Tidak Setuju, Sangat Tidak Setuju. Indikator pada kemampuan komunikasi matematis pada penelitian ini ialah mengacu pada Sumarno dalam Karlimah (2010) yang berisikan pembalajaran dengan menggunakan benda, gambar dan diagram, yang sesuai dengan peristiwa dalam kehidupan. Selain itu, terdapat penyataan yang berupa bagaimana siswa dalam penyampaian informasi.

Tes tulis kemampuan pemecahan masalah mendapatkan data berdasarkan Polya dalam Ismuniyati (2019) yang berisikan mengenai kecakupan data dan menerapkan strategi pemecahan yang berupa masalah kehidupan baik secara matematika atau diluar matematika menjadi indikator pada kemampuan ini. Dalam penilaian pada soal tersebut 1 soal mendapatkan 20 point dan bila tidak lengkap atau tidak selesai hingga sempurna maka mendapatkan 10 point.

Setelah mendapatkan hasil dari tes kemampuan tersebut maka data akan duji regresi dengan pengujian pra-syaratnya yaitu uji normalitas, uji anova regresi untuk mendapatkan pola pada analisis tersebut, uji-t untuk mengetahui pengaruh signifikan kemampuan tersebut dan koefisien determinasi melihat berapa pengaruh komunikasi matematis siswa terhadap kemampuan pemecahan masalah.

\section{HASIL PENELITIAN DAN PEMBAHASAN}

Dari penelitian tersebut didapatkan data yang berupa tes tertulis dan pernyataan.

Tabel 1. Rangkuman Hasil Uji Normalitas Residu Kemampuan Komunikasi Matematis terhadap Kemampuan Pemecahan Masalah

\begin{tabular}{|l|l|l|l|l|}
\hline Kelompok Sampel & L $_{\text {hitung }}$ & L $_{\text {tabel }}$ & Sig & Keterangan \\
\hline Residu & 0.109 & 0.254 & 0.200 & Normal \\
\hline
\end{tabular}

Dari tabel 1, terlihat bahwa data tersebut berdistribusi normal karena pada $\mathrm{L}_{\text {hitung }}<\mathrm{L}_{\text {tabel }}$ sehingga $\mathrm{H}_{0}$ diterima dan $\mathrm{H}_{1}$.

Tabel 2. Rangkuman Hasil Uji Anova Regresi Kemampuan Komunikasi Matematis Terhadap Kemampuan Pemecahan Masalah

\begin{tabular}{|l|l|l|l|l|l|l|l|}
\hline $\begin{array}{l}\text { Sumber } \\
\text { Variansi }\end{array}$ & $\begin{array}{l}\text { Jumlah } \\
\text { kuadrat }\end{array}$ & Df & $\begin{array}{l}\text { Rata- } \\
\text { rata } \\
\text { Jumlah } \\
\text { kuadrat }\end{array}$ & $\mathbf{F}_{\text {hitung }}$ & $\mathbf{F}_{\text {tabel }}$ & Sig & Keterangan \\
\hline Regresi & 101.011 & 1 & 101.011 & 1.567 & 4.24 & 0.222 & $\begin{array}{l}\text { Tidak } \\
\text { signifikasi }\end{array}$ \\
\hline Residu & 1611.655 & 25 & 64.466 & & & & \\
\hline Tuna & 1057.739 & 9 & 117.527 & 3.395 & 2.54 & 0.16 & Tidak \\
\hline
\end{tabular}




\begin{tabular}{|l|l|l|l|l|l|l|l|}
\hline cocok & & & & & & & $\begin{array}{l}\text { berpola } \\
\text { linier }\end{array}$ \\
\hline Galat & 533.917 & 16 & 34.620 & 34.620 & & & \\
\hline Total & 1712.667 & 27 & & & & & \\
\hline
\end{tabular}

Dari tabel 2. Didapatkan yang pertama, nilai $F_{\text {hitung }}$ tuna cocok lebih besar dari $F_{\text {tabel }}$ maka $\mathrm{H}_{1}$ diterima. Sehingga didapatkan kemampuan tersebut tidak berpola linier.

Dari tabel 2. Didapatkan yang kedua, nilai regresi $F_{\text {hitung }}$ lebih kecil daripada $F_{\text {tabel }}$ sehingga $\mathrm{H}_{1}$ diterima. Maka kemampuan komunikasi matematis terhadap kemampuan pemecahan masalah tidak ada perubahan signifikan.

Tabel 3. Rangkuman Hasil Uji - T Kemampuan Komunikasi Matematis Terhadap Kemampuan Pemecahan Masalah

\begin{tabular}{|l|l|l|l|l|l|l|}
\hline Model & B & $\begin{array}{l}\text { Std. } \\
\text { eror }\end{array}$ & $\begin{array}{l}\text { Standar } \\
\text { koefisien } \\
\text { Beta }\end{array}$ & thitung $_{\text {tabel }}$ & Sig \\
\hline Konstant & 67.241 & 7.600 & & 8.848 & & 0.00 \\
\hline $\begin{array}{l}\text { Komunikasi } \\
\text { Matematis }\end{array}$ & 0.134 & 0.107 & 0.243 & 1.252 & 2.7701 & 0.222 \\
\hline
\end{tabular}

Dari Tabel 2. Didapatkan nilai persamaan regresi adalah

$$
y=67.241+0.134 x
$$

Dari data tersebut didapaykan bahwa kemampuan komunikasi terhadap kemampuan pemecahan masalah tidak berpengaruh signifikan dikarenakan $t_{\text {hitung }}$ lebih besar dari $t_{\text {tabel }}$ sehingga $\mathrm{H}_{1}$ diterima. Jika kita lihat pada Tabel 2. Maka kita dapatkan $\mathrm{t}_{\text {hitung }}<\mathrm{t}_{\text {tabel }}$ sehingga didapatkan $\mathrm{H}_{1}$ diterima dan $\mathrm{H}_{0}$ ditolak.

Tabel 4. Koefisien Determinasi

\begin{tabular}{|l|l|l|l|}
\hline $\mathrm{R}$ & $\begin{array}{l}\text { Koefisien } \\
\text { determinasi }\end{array}$ & Standar eror & Kesimpulan \\
\hline 0.243 & 0.059 & 8.029 & Pengaruh 5.9\% \\
\hline
\end{tabular}

Dari Tabel 3. Kita dapatkan bahwa tingkat pengaruh kemampuan komunikasi terhadap kemampuan pemecahan masalah sebesar 5.9\%. didapatkan dari koefisien determinasi ya

Dari pengujian yang dilakukan maka didapatkan bahwa tidak adanya pengaruh signifikan antara kemampuan tersebut dapat dilihat dengan uji anova regresi yang didapatkan bahwa tidak ada pola linier pada kemampuan tersebut dan pada hasil uji - $\mathrm{t}$ didapatkan bahwa tidak ada pengaruh signifikan antara komunikasi matematis terhadap kemampuan pemecahan masalah bila dilihat pada koefisien determinasi pengaruh komunikasi sangatlah kecil yaitu 5.9\%. Hal ini sejalan dengan penelitian Karimah pada "Kemampuan Komunikasi dan Pemecahan Masalah Matematis Mahasiswa Pendidikan Guru Sekolah Dasar Melalui Pembelajaran Berbasis Masalah" yang menyatakan bahwa 
pada tidak adanya interaksi antara keduanya di karenakan pada pengujian interaksi nilai $\mathrm{p}$ - value lebih dari 0.005 .

\section{KESIMPULAN}

Dapat disimpulkan bahwa kemampuan komunikasi terhadap kemampuan pemecahan masalah pada siswa SMP kelas 9 tidak berpengaruh antara keduanya. Tingkat pengaruh kemampuan tersebut sebesar $5.9 \%$ dan $93.1 \%$ dipengaruhi oleh variabel lain.

\section{REFERENCES}

Juanda, M., Johar, R., \& Ikhsan, M. (2014). Peningkatan kemampuan pemecahan masalah dan komunikasi matematis siswa SMP melalui model pembelajaran Means-ends Analysis ( MeA ). Kreano, 5(November), 105-113.

Wulandari, I. A. D., Suarsana, I. M., \& Pujawan, I. Gu. N. (2018). Model pembelajaran kooperatif talking stick, mind mapping, dan kemampuan komunikasi matematis. MaPan : Jurnal Matematika Dan Pembelajaran, 6(1), 82-93.

Monica, H., Kesumawati, N., \& Septiati, E. (2019). Pengaruh model problem based learning terhadap kemampuan pemecahan masalah matematis dan keyakinan matematis siswa. MaPan : Jurnal Matematika Dan Pembelajaran, 7(1), 155-166.

Prabawanto, S. (2013). Peningkatan kemampuan pemecahan masalah komunikasi dan self-efficancy matematis mahasiswa melalui metacognitive dcaffolding.Unpublished Thesis.

Ismuniati. (2019). Pengaruh komunikasi matematika terhadap kemampuan pemecahan masalah matematika.Unpublished Thesis. Mataram : Universitas Islam Negeri Mataram

Ariawan, R., \& Nufus, H. (2017). Hubungan kemampuan pemecahan masalah matematis dengan kemampuan komunikasi matematis siswa. THEOREMS (The Original Research of Mathematics), 1(2), 82-91.

Karlimah. (2010). Kemampuan komunikasi dan pemecahan masalah matematis mahasiswa pendidikan guru sekolah dasar melalui pembelajaran berbasis masalah. Jurnal Pendidikan, 11(4), 51-60.

Siti, F., Syarifah, D., Nuraidah, S., Lexbin, M., Judah, E., \& Maya, R. (2018). Analisis pengaruh disposisi matematis terhadap kemampuan pemecahan masalah matematis siswa smp. JPMI : Jurnal Pembelajaran Matematika Inovatif, 1(2), 201-206.

Husna, M.Ikhsan, \& Fatimah, S. (2013). Peningkatan kemampuan pemecahan masalah dan komunikasi matematis siswa sekolah menengah pertama melalui model pembelajaran kooperatif tipe Think-Pair-Share(TPS). Jurnal Peluang, 1(April), 81-92.

Tanjung, S. A. H., \& Amalia, Y. (2019). Pengembangan bahan ajar problem based learning kemampuan pemecahan masalah materi SPLTV. Jurnal Ilmiah Pendidikan Matematika AlQALASADI, 3(1), 70-80.

Anggreni, F. (2019). Relevansi pembelajaran matematika dengan nilai - nilai Al-Qur'an dalam membentuk karakter siswa pada materi pecahan. Jurnal Ilmiah Pendidikan Matematika AlQALASADI, 3(1), 10-18.

Wahyuni, Z., Roza, Y., \& Maimunah. (2019). Analisis kemampuan penalaran matematika siswa kelas x pada materi dimensi tiga. Jurnal Ilmiah Pendidikan Matematika Al-QALASADI, 3(1), 81-92.

Wahyuni, M.Ikhsan, \& Bahrun. (2019). Aktivitas siswa dalam pembelajaran matematika dengan menggunakan pendekatan scientific. Jurnal Ilmiah Pendidikan Matematika Al-QALASADI, 3(1), $56-63$. 
Estiningrum, T., Hidayati, D. W., \& Wahyuni, A. (2019). Analisis kemampuan pemecahan masalah matematis siswa melalui implementasi pogil ditinjau dari gaya kognitif. Jurnal Ilmiah Pendidikan Matematika Al-QALASADI, 3(2), 69-75. 